\title{
The Power of the Will of Faith and the Point of View of Islam
}

\author{
Adnan A. Al Smadi \\ Faculty of Sharia Jerash University, Jerash, Jordan \\ Email:dsmadi@rambler.ru
}

How to cite this paper: Al Smadi, A.A. (2019) The Power of the Will of Faith and the Point of View of Islam. Modern Economy, 10, 2450-2462.

https://doi.org/10.4236/me.2019.1012154

Received: November 6, 2019

Accepted: December 28, 2019

Published: December 31, 2019

Copyright (C 2019 by author(s) and Scientific Research Publishing Inc. This work is licensed under the Creative Commons Attribution International License (CC BY 4.0).

http://creativecommons.org/licenses/by/4.0/

\begin{abstract}
In this paper we present the Will of Faith and the Point of View of Islam confronting the free world because of its adherence to the principle of economic freedom, which calls for the rule "let him work, let him pass." This principle has brought about deep inequality between the rich and the poor, where the rich are a bit more than $10 \%$ of the population possessing $90 \%$ of the wealth, whereas the rest of the population does not have more than $10 \%$ of it. This is due to the wrong view of the free world about the economic problem caused by the relative scarcity based on Metros theory. In his theory, Matros, argues that the increase of population follows the engineering progression $(1,2,4,8$, $16, \cdots)$ and the arithmetical progression on the increase of the wealth $(1,2,3$, $4,5,6)$. This theory has been adopted by the free doctrine people to solve the problem by increasing the size of the national income without intervening in the distribution of wealth that would reach the hands of each individual. Hence, the one who has the wealth is the one having the capital. Islam, on the other hand, believes that the economic problem is due to bad distribution of wealth and that solving the problem is achieved by ensuring the accessibility of wealth by each citizen, increasing production, and controlling contracts and conditions. The related work that the power of will over contracts and conditions through controlling the possession of wealth and fair distribution of it guarantees the needs of each individual and creates an economic balance so as to prevent the encroachment of the individual on society and the encroachment of society on the individual.
\end{abstract}

\section{Keywords}

Satisfaction, Faith on Contracts, Poverty, Concluded, View of Islam

\section{Introduction}

The economic problem over the ages is a subject of controversy and interest. As 
man has been unable to satisfy his organic needs and meet his desires, so he started to search for the causes of this problem and methods of treatment. Some people consider the relative scarcity of goods and services in exchange for unlimited needs is the economic problem. Some, however, think that the poor distribution of wealth is the problem. Based on the two different viewpoints, people were different regarding the treatment methods. People who believe in the first point of view stated that the treatment of the problem can be reached by increasing the national income and production, obtaining resources. Therefore, they are calling for economic freedom in production and distribution. People of the second view believe that the problem can be solved through fair distribution of wealth, restriction of ownership or restriction of possession of wealth.

People of the first opinion are the followers of the free-market, a school of thought, who call for economic freedom, which is the dominant view of the world and its results are evident, where $90 \%$ of the people have $10 \%$ of the income and $10 \%$ of the people have $90 \%$ of the wealth and income. This type of economy will give more poverty and misery [1] [2] [3].

And adjust the possession of wealth and transferred from one person to another or other State contracts.

This consideration is based on the theory of commitment that obligates the individual to be free to contract. He committed himself to whatever harm he suffered from this. The lawmakers pushed the theory of injustice on some contracts and expanded to include an impact on the theory of commitment to the corruption of its predecessors before the use of mechanical machinery and industry and the presence of wars, which prompted the theory to develop a theory of condition and interest that have developed similar theories such as insurance, including the theory of compliance, and forced pricing and forced estimation of wages.

The people who believe that the problem lies in bad distribution of wealth have been divided into two groups: socialists and communists; they say that the economy belongs to people and not to individuals expect that portion necessary to satisfy basic needs; they also call for the prevention of individual ownership. People of this, a school of thought, failed, and their power collapsed and returned to capitalism.

Islam, whose source is revelation, confirms that poverty is caused by poor distribution of wealth, lack of discipline regarding possession, consumption, distribution, and non-activation of economic resources. The most important cause is the lack of qualifying human resources. Therefore, Islam controls possession and ownership, through means that guarantee wealth to reach every individual in the country and enable him to satisfy his basic needs and give him the freedom to satisfy all his desires, but with restrictions and controls [4] [5] [6] [7].

The most important of these restrictions and controls is the legislation of the so-called contracts Some of these controls and restrictions control freedom in contracts and conditions. This research includes two sections and a set of re- 
quirements:

The first topic: freedom of contracting and the role of consent in establishing contracts.

The second requirement: the freedom of stipulating conditions in contracts and arranging their effects.

The first topic: The first requirement: It includes the terms related to the research, which are:

1) The inner will: the intention and intent, which is not seen by anyone.

2) The apparent will: it is the formula that expresses the inner will or whatever stands for it, such as the dealing with exchange contracts and other ones.

3) Choice: is merely the purpose of the statement, that is, self-affirmation and acceptance or whatever stands for it. It is what the intended person is capable of doing, which varies between the possibility or and non-possibility of man ability, by giving more weight to one side one the expense of the other.

4) Satisfaction: is the satisfaction of the self for the work it desires to do; it is defined by Muslim jurists as the desire of accepting the consequences of contract with regard to making the contract subject to Islamic provision when it comes into existence and established.

5) Contract: is the legal link between affirmation and acceptance, which proves that the contract is correct.

\section{Role of Satisfaction in Establishing Contracts}

The basis of contracts is the will of the contractor perceived from his statement, or the coincidence of the two wills whose appearance is indicated by affirmation and acceptance. Based on what is stated above. There will be two elements, which cannot be achieved. The first element is the choice and the second is satisfaction.

The choice is the intent to do an act that a person can do, whether the act is a word or not. The choice in the contract is the intention to utter the words according to which the contract was established, as long as he can utter those words deliberately and that he intends to pronounce them [8] [9] [10].

Satisfaction is the state of the self with regard to the work it desires to do, namely the desire to accept the consequences of the contract with regard to the stipulated legal provision in the contract upon existence and establishment. Bazdawi defined it as full capability to do the act until its end, so that its effect will lead to apparent appearance of satisfaction on the face and the like [11].

The difference between satisfaction and choice is that the choice is merely the intention of the reason which is the statement or is what stands for. Satisfaction is the desire for the effects and the consequences which are the provision of the contract. Satisfaction always includes the choice but not the opposite. This means that the choice may exist without satisfaction. Scholars say that the first biases of criticizing the contract is the achievement of choice, because it leads to the existence of the contract and the creation of its form. Satisfaction, on the 
other hand, is the condition for correctness of most contracts and arranging their effects [12].

For the Shafi's, the choice and satisfaction are inseparable, so the mere choice is not achieved upon satisfaction. Likewise, Satisfaction is not achieved without choice. They are two synonyms, indicating the intention of the contractor through his statement that reveals what his desire is to establish the contract in order to reach the effects arranged by the legislator. According to this, scholars said that the statement by the unserious person is right since he chooses the statement freely without a difference between acts subject to cessation like selling or rent and acts that are not subject to cessation like divorce and return [13].

The Maaliki's and the Hanbali's agree with the Shaafi's that satisfaction and choice are inseparable, that is, no one of them exists without the other. However, they differ regarding who is referring to in the statement establishing the contract without the desire for the consequences thereof. This is not regarded choice or satisfaction by them. An example of this is the statement of the unserious or the forced person since neither of them like the effects resulting from the contract. So, if the contract exists, it does not indicate satisfaction and choice.

Based on the above, the Hanafi's decide that satisfaction and choice are two different things, whereas satisfaction and choice for non Hanafi's are the same, taking into consideration that the Sahafi's agreed with the Hanafi's that the choice indicates satisfaction because they are inseparable.

We conclude that the meaning in the contracts, for the Shari's and Hanafi's in some branches, is that of the words and linguistic structures, not for purposes and meanings, whereas for others, the meaning in contracts refers to purposes and meanings and not for words and structures.

\section{The Effect of This Disagreement Emerges in the So-Called Sham Contracts or the Mismatch of the Two Wills as in the Following Cases}

1) The state of drunkenness, sleep, insanity, fainting and non-discrimination, where the contracts issued during these cases will have no effect, because of the lack of real will in establishing the contract.

From the mentioned cases, they excluded drunkenness; the al-Maliki's and Hanbali's do not consider the acts of drunkenness, which was applied in most personal status laws in the Islamic world [14].

The Hanafi's, Maliki's and Hanbali's agreed not to consider the words and actions of the drunk person as permissible, but they opposed them in considering the drunk person deeds and words Muharram (impermissible) as a punishment and blame for him, so his contracts like selling and marriage are correct, and his acts, such as divorce are correct, and their effect are valid.

2) The words of the wrongdoer and the person who forgets: anyone who commits a wrong act or forgets and utters words that result in commitment, their words shall have implications according to Hanafi's. Most fuqah'a (Islamic 
jurists) state that the words of wrongdoers and those who forget do not entail effects, and are not binding because they do not mean commitment, so he is not blamed for what he does not intend to say as Allah says "And there is no blame upon you for that in which you have erred but [only for] what your hearts intended" [15]. They quoted the Prophet saying (PBUH) if a presumption is based on error and forgetfulness: "Verily Allah has pardoned [or been lenient with] for me my ummah: their mistakes, their forgetfulness, and that which they have been forced to do under duress."

3) The words of the unserious person: The person who wants to say something in a way opposite to the real meaning or what statement is valid for metaphorically. The views of the Hanafi's, Maliki's and Hanbali's agreed that the statement has no effect except in the five contracts of marriage, divorce, return, freeing the slave, and oath. The Shaafi's, however, opposed them in that the statement is valid for establishing contracts.

4) The word of the forced person: if the initiator of the statement has been forced to utter it, and he uttered it to escape the harm from a person threatening him, which he cannot stand, with the ability of the threatening person to carry out what he has impended and the threatened person did not want the consequences resulting from his words. Alhanfi's say that the words of the forced person are valid for all types of contracts. Others, however, argue that the forced person will not be obliged by his words and they shall not entail a legitimate ruling [16].

5) The illegal intention, such as selling arms to the people of sedition, selling juice to those who take use it as wine, Al-Ina selling (to sell the item at a deferred price, and then buy it again in cash at a lower price without a broker), the marriage of the "billy-goat" (a man who marries the divorced woman, consummates the marriage with her, then divorces her, and he is given a sum of money in return for that!). Al-Shafei argues that the contract is correct and has effects on the contract. Other Islamic (fuqah'a) jurists opposed him, saying the contract is not valid, and that affirmation and acceptance do not have any effects when there is evidence about the contract, as well as the differed sale and the exchange sale, where two people pretend or collude to conclude a contract between them to get rid of unjust aggression or to show amount greater than the real one for fame or reputation purposes... etc. [17] and the inner will or the so-called sham contracts in four cases:

First: when that the statement is not intended at all, such as the statement of the insane, the unconscious and the boy who is not capable of recognition or when the contractor is not intended like the words of Mulaqin (prompter) or for the purpose of keeping by heart or education.

The statement is intended according to its linguistic meaning for the purpose of reaching to a forbidden matter, such as selling weapons to the people of war, i.e., the aggressor, Al-Ina selling (buying a commodity at differed price and selling it in cash), and the Billy-goat marriage. 
Third: to pretend that he is contracting without his desire in its impact, such as the unserious person, like the one who declares unreal dowry or a price.

Fourthly: the expression tool should not be expressing the inner will according to its linguistic status, such as the use of the term "Ijara" (rent) instead of sale, and the use of the term "gift" instead of marriage. This difference between the two wills is resulted from disagreement in the previous issues and whatever falls within them.

The third requirement: the freedom to establish contracts (freedom of contract): Madahib (doctrines of jurisprudence) are different in two opinions regarding the principle of freedom of contract formation, namely, choosing a particular system to form a contract between the two parties in the new transactions:

The first view: the Dhahiri a school of thought (doctrine), who are the followers of Daoud al-Dhaheri and Ibn Hazm; they stated that the origin of contracts is prohibition until evidence based on permissibility exists, that is, every contract not proven by a text from the Nobel Qur'aan or Sunnah or consensus of jurists [18].

The second view: it is the view of the public (Hanafi's, Maliki's, Shaafai's and Hanbali's) who are tolerant said: The origin of contracts and the related conditions is permissibility unless forbidden by Sharia (law) or contradict a legal text.

Al-Dhahri's based their view on the Sunnah and reasonableness:

1) From the Sunnah:

a) The Prophet's saying (PBUH) "The Messenger of Allah said", "He who innovates something in this matter of ours (i.e., Islam) that is not of it will have it rejected (by Allah)." [Bukhari \& Muslim] In another version in Muslim it reads: "He who does an act which we have not commanded, will have it rejected (by Allah)." (Narrated by al-Shaykhan); every contract that is not prescribed by sharee'ah or consensus is null and void [19].

b) The prophet (PBUH) says "Why do some people impose conditions which are not present in Allah's Book (Laws)? Whoever imposes such a condition as is not in Allah's Laws, then that condition is invalid even if he imposes one hundred conditions, for Allah's conditions are more binding and reliable." (Narrated by Muslim). This means that the condition if not stipulated in a text is invalid and the contract is measured accordingly.

The scholars infer their opinion that the origin of contract is permissibility unless there are no evidence indicating otherwise in the Nobel Quran and Sunnah.

1) From the Nobel Quran Allah says $O$ you who have believed, fulfill [all] contracts (Al-Maaida, 1) The verse enjoined the fulfillment of every contract without exception, that is, it stipulates the principle of compulsory force and requires man to fulfill his contract which he initiated with his free will.

2) The Sunnah: The Prophet (PBUH) says Reconciliation is allowed among the Muslims, except for reconciliation that makes the lawful unlawful, or the 
unlawful lawful. (A hadeeth is saheeh narrated by Ibn Majah and Abu Dawud and al-Tirmidhi) (Wahba Al-Zhaili, 199/4-200).

It is more likely that contracts are deeds and not things. Therefore, the rule of jurisprudential origin is that things are originally permissible and the origin of acts is to abide by the Islamic ruling.

Based on this rule, contracts are allowed by Islamic law in the general text.

In the Holy Quran,

"O you who have believed, fulfill [all] contracts" (Almaida, 1) and in the general terms of the Prophet's sayings, acts and agreements (PBUH).

Based on what has been mentioned above, the contracts, whose elements and conditions are complete, are considered permissible. All that applies to the definition of the contract, that is, a link between affirmation and acceptance by a legitimate basis that proves its impact, whether the contracts are old or new, and any new contracts will fall under the definition of the contract and its permissibility.

We conclude by saying that it is the will of faith that constitutes the absolute power to establish contracts, stipulate conditions, define the obligations of contractors and their effects within the limits of God's law and what he has specified.

Hence, the rule "the contract is the law of contractors", emerges, that is, a binding law for both parties in the contract as stated in Jordanian, Syrian and Egyptian civil laws, Article 148/1 in the Syrian law, and Article (108) in the Egyptian Civil Code.

The second topic is the freedom of setting conditions and arranging effects of contracts. The first requirement is the form of the contract when combined with the condition. The form may be issued in absolute form free from the terms and restrictions, upon which effects occur when the two contractors believe that they meet the intended purpose.

The two contractors or any one of them might feel that the wording in itself does not achieve the purpose or the need for which the contract was established. So, the two contractors or any of them may increase or decrease the contract by putting a condition set by one of them and accepted by the other. In this case, the form is issued in conjunction with certain conditions and restrictions, which change the effect of the prescribed version of the contract formula [20] to meet the What is the authority of Fuqaha' (jurists) to devise new formulas for contracts or modify the original effects of the contract in case the contractors require contractual conditions by either adding or decreasing. However, Sharia does not give protection to all conditions required by people in their contracts, but rather gives such protection to its appropriate conditions and gives no protection to conditions violating Sharia. And an example of prevention given by Sharia is the new laws dealing with conditions contrary to the public order. However, what controls the allowed reasonable conditions and the unreasonable ones in Islamic law. These conditions may be according to contractors' desires, 
and thus they do not stop at a certain limit. So the legislators do not leave these conditions for the whims and purposes, but they opt to the permissibility of some conditions that satisfy some desires, and at the same time do not run counter to contract requirements [21]. Islamic jurisprudence differed on three opinions regarding the principle of free contract establishment (freedom of contract), namely, the choice of a particular legislation to be a contract between two parties, or the choice of a particular type of contract, in addition to the familiar contracts of the past. No condition is considered except those stated and proven by a text, and when there is proof or evidence indicating that it must be fulfilled. People following is a school of thought (doctrine) limit evidence in the text and consensus. Measurement, custom and other pieces of evidence are not considered by them in the legislation of provisions [22].

People holding this view support their opinion by relying on the Prophet's saying (PBUH): "Whoever does something that is not in the Book of Allaah is invalid, even if it is one hundred conditions." Narrated by Muslim.

Abu Hanifa said that the origin of contracts and the related conditions is permissibility, unless prohibited by Shariah' "or contravenes the provisions of Shariah". Abu Zahra says that every condition that has no evidence in Sharia indicating that its forbidden and not taken into consideration, so it is a binding obligation that must be fulfilled without restriction under the contract because people will be held to their conditions, and they have to fulfill their covenants. If they tried to break down their covenants and escape from their limitations, the judiciary system obliges them to carry out their fulfillment. For example, when a woman puts a condition that her husband should not marry another woman and should not move her to a country other than her own.

They based their opinion on the general meaning of Qur'an, "O you who have believed, fulfill [all] contracts" (Almaida, 1), and by using qiyās (deductive analogy) conditions on reconciliation. Reconciliation is permissible among Muslims except for reconciliation that makes halal (lawful) unlawful (haram), or the unlawful lawful. "Reconciliation is allowed among Muslims, except for reconciliation that makes the lawful unlawful, or the unlawful lawful. And the Muslims will be held to their conditions, except the conditions that make the lawful unlawful, or the unlawful lawful" [23].

The public fuqah'a (Islamic jurists) say that the origin in contract is prohibition (prevention) and they exclude some of them and extend in this exception. They considered every condition generating a benefit as an increase to the origin of the contract and a violating condition that spoils the financial exchange contract. In non-financial exchange contract, such as marriage, the condition is invalid or annulled and the contract is correct (Alhkafif ala almuamalat, p. 213; Zuhaili 4/199).

The law permits that the contract may be accompanied by a condition or a condition can be added to the contract for a certain period of time (Ibn al-Qayyim, Zaid al-Maa'd 4/4). The Egyptian, Syrian, and Jordanian civil law 
adopted this notion and the law states that "the contract is the law of contractors".

The second requirement: the power to modify the effects of contracts.

Shari'a (Islamic law) and civil laws agree that the effects and provisions of contracts are the will of legislator, and they are not the task of contractors. "It is the will of contractors that establish the contract, but the law is the body that stipulates the effects and provisions of each contract. The man's will is limited to the establishment of the contract only, like the contract of sale, but with regard to the consequences of the contract, such as transferring ownership of the sale to the buyer and entitling the buyer to get the price from the seller is left to the discretion of the Shari'a. The wills of the two contracting parties derive their authority from Shari'a with the limits set for each contract" (Al-Zuhaili, 4/201)

The conditions might meet the need of contractors. These conditions, however, may not meet the needs of contractors. In this case, what is the extent to which the contractors have the authority to modify the effects of the contracts or what is the validity of the jurists to devise the limits prescribed in the law or to modify the original effects of the contract by increasing or decreasing conditions.

The Fuqah'a (Islamic jurists) have three opinions concerning the freedom to stipulate conditions in contracts, which are:

- Prevention, the origin of contracts, conditions and prevention. Every condition that is not approved by Shari'a or unanimity is faced (corrupt) and this is the view of Al-Dahira as stated before.

- The second is permissibility, i.e., the origin of contracts and condition is permissibility that is the opinion of Hanbali's.

- The third is restriction according to Hanafi's, Maliki's and Shaafi's as mentioned previously. Fuqah'a (Islamic jurists) have two opinions with regard to the amendment of the effects and provisions of contracts and this is part of the legislator' authority and not pertaining to the contractor, and they are:

1) The first is that of Al-Dahiria. They say that the origin of contract is prohibition and the origin of conditions prohibition. Any condition that is not approved by Shari'a through a text and consensus is invalid. No condition is considered as one of the conditions except what is stated in the text, and there is a proof indicating that it must be fulfilled, because legal obligations do not take its strength from the words and wills of the contractor, but from what the legislator decides based on contractors' statements, and he judges that it is the effect of their behavior. If there is no evidence from the legislator to consider the conditions set by contractors, they are not taken into account and judged as having no effect, and they will not have the power to be carried out. (Abu Zahra, 237/274)

2) The second, it is for the other jurists who say that the origin of contracts and condition is permission, but they are divided into two groups:

a) Hanbali's: every condition where the Sharia does not have evidence of prohibition, and there is no evidence indicating that it is not considered, so it is 
binding and must be fulfilled without restriction under the contract, because people are held by their conditions, and they should fulfill their covenants. If they retreated or tried to escape the restrictions of conditions, the Judiciary system shall force them to fulfill them (Al-Zarqas, 215; Al-Zuhaily, 4/202; Abu Zahra, p. 172, Ibn al-Qayyim, 4/25, Ibn Taymiyah, p. 220, Ibn Qudamah 4/232).

b) Other than Hanbali's: They say that the origin in the conditions of the contract is restriction, for every condition violating the law or the contract is invalid, but other conditions are correct.

From the above, the release of conditions under the rules of Hanbali's, meets the needs and interests of the people and commensurate with the developments and customs in the conclusion of contracts for legitimate purposes, otherwise the law will stop at what is stipulated by the contracts and close the door of Ijtihad (independent reasoning) in the coming transactions, especially because the field of economic activity expands in contracts and conditions day by day and this occurs in the financial contracts. In marriage contracts, however, Al-Dahira opinion is considered in order to protect sanctity and holiness of the contract and because it involves an aspect of worship, and as the family is characterized by stability and permanence, so the freedom of condition that is affected by inclination that blows the marriage high purposes should not be allowed. His purposes of marriage are high. Fuqah' (Islamic jurists) "the origin of Alibda" (sexual pleasure) is altharim (prohibition) "(Al-Zoheily 4/202)".

All these are general terms, but in a detailed a madhab (a school of thought), different madhib (schools of thought) differ: the Hanafi's, Maliki's and Shaafi's (the public) agreed generally on the requirements of contracts, but they differed in the legitimate conditions in contracts and the illegitimate ones because of the texts contained in the Qur'an and Sunnah.

A group of them adheres to the explicit wording of the text, which does not allow the two contracting parties to put a condition that is not mentioned in the Qur'an, Sunnah and consensus. They restricted conditions in two valid and invalid categories. The correct category is the one mentioned in a text or unanimity, whereas the void category is the one that is not mentioned in a text or unanimity, indicating its permissibility, whether the contract is a gratuities contract or an exchange contract.

Hanbali's and Ibn al-Qayyim argue that contractors have the right to put any condition consistent with their purposes, unless forbidden in Islamic law, and unless the condition is due to the contractors to delete or cancel. It was narrated that Umar (MABPH) said "rights are due to conditions".

The Hanafi's disagreed with and Hanbali's and believe that the origin of conditions is prohibition, but they exclude some of them and expand in the exception to include the conditions allowed in the law, such as the requirement to postpone the price of sale and the requirement of choice for one of the two parties of the sale. They also excluded the conditions that fit the contract, such as the sponsor's condition and that of the pledge, because it is a documentation of 
the contract. They also excluded the conditions based on custom which is considered legitimate, such as delivery of goods to the buyer, and the seller ensures that the sale is faultless for a certain period. If the condition is one of the three previous types, it is considered a valid condition that must be met by the committed person. If the time of condition was not met, the other party has the option to cancel or complete the contract (Abu al-Einin, p. 425, Abu Hurayrah, p. 276).

If the condition is not one of the four previous types, which are:

The one in accordance with the contract, or the one confirming the contract, or the one decided by the law, or accepted in custom, but it includes extra benefit for one of the contractors as the purchase of wheat to be grinded by the seller and the purchase of cloth that the seller should sew it into a shirt which is a condition that was not one of the correct types and has no benefit for any of the contractors or for any other party, but it includes harm to one of the contractors, such as the seller's requirement on the buyer that he should not sell the item, and the requirement of the seller of the car on the buyer not to be used by a certain person, the contract is correct and the condition is invalid, whether in the exchange contract or in other types. Considering the previous Madahibs (schools of thought), regarding conditions associated with contracts, we find that the Hanbali's madhab (school of thought) is the broadest school of thought with regard to permitting conditions. This school of thought is consistent with modern commercial custom, and It does not distinguish between contracts [24].

In the Egyptian Civil Code, the Egyptian legislator has adopted the position of those who say that the contract may be linked with a condition. This is stipulated in Article (147) which states that the contract is the law of the contracting parties, and they may add the conditions they want, and control the impact of the contract by subjecting the contract to their desires because the contractor concludes the contract by his free will and he is the one who creates the contract and its effect [21].

\section{Conclusions and Recommendations}

In order to contribute to the field and not to repeat the opinions of school thoughts, that is by recommending solutions to the modern time economic problems. The possession of wealth and fair distribution of it guarantees the needs of each individual and creates an economic balance so as to prevent the encroachment of the individual on society and the encroachment of society on the individual.

The contract is the law of the contracting parties and it is valid if all the conditions and conditions are met.

\section{Recommendations}

Through Thresher that personal freedoms and economic freedom under the theory of commitment even with the amendments have not solved problems resulting from an update on developments in relations individual and internation- 
al, as they did not take the controls and restrictions of individual already, and in financial transactions and international relations, it was necessary to amend the provisions legal in all areas, restrictions and controls to freedom in general Muslim guarantee personal and sexual intercourse and states with operationalization power of the will of on contracts and conditions and operationalization base (In relation to observance, a provision should be elaborated on act, in which the binding nature of such State acts was examined.

\section{Acknowledgements}

The Deanship of Scientific Research, Jerash University, supported this Work.

\section{Conflicts of Interest}

The author declares no conflicts of interest regarding the publication of this paper.

\section{References}

[1] Nasr, S.H. and Religion Sphilosoph, I. (2010) Islam in the Modern World: Challenged by the West, Threatened by Fundamentalism, Keeping Faith with Tradition. HarperOne, New York.

[2] Brumberg, D. (2005) Islam Is Not the Solution (or the Problem). The Washington Quarterly, 29, 97-116.

[3] Al-Asad, T. (2009) The Idea of an Anthropology of Islam. Qui Parle, 17, 1-30. https://doi.org/10.5250/quiparle.17.2.1

[4] Stone, L.A. (2002) The Islamic Crescent: Islam, Culture and Globalization. Innovation: The European Journal of Social Science Research, 15, 121-131. https://doi.org/10.1080/1351161022000001269

[5] Halstead, M. (2004) An Islamic Concept of Education. Comparative Education, 40, 517-529.

[6] Fauzia, A. (2013) Faith and the State: A History of Islamic Philanthropy in Indonesia (Vol. 1). Brill.

[7] Endresen, C. (2015) Faith, Fatherland or Both? Accommodationist and Neo-Fundamentalist Islamic Discourses in Albania. In: The Revival of Islam in the Balkans, Palgrave Macmillan, London, 222-241.

https://doi.org/10.1057/9781137517845_12

[8] Ghafouri-Fard, S. and Akrami, S.M. (2011) Man Evolution: An Islamic Point of View. European Journal of Science and Theology, 7, 17-28.

[9] Schurich, C. and شروش كيرديس. The Vision of Islam: The Foundations of

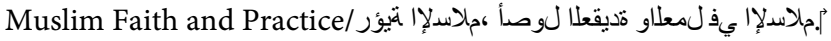

[10] Lane, J.-E. and Redissi, H. (2016) Islam: Faith and Rationality. In: Religion and Politics, Routledge, London, 79-88.

[11] Stone, L.A. (2002) The Islamic Crescent: Islam, Culture and Globalization. Innovation: The European Journal of Social Science Research, 15, 121-131. https://doi.org/10.1080/1351161022000001269

[12] Bannerman, P. (2013) Islam in Perspective (RLE Politics of Islam): A Guide to Islamic Society, Politics and Law. Routledge, New York. https://doi.org/10.4324/9780203381397 
[13] Rayan, S. (2012) Islamic Philosophy of Education. International Journal of Humanities and Social Science, 2, 150-156.

[14] Back, L., Keith, M., Khan, A., Shukra, K. and Solomos, J. (2009) Islam and the New Political Landscape: Faith Communities, Political Participation and Social Change. Theory, Culture \& Society, 26, 1-23. https://doi.org/10.1177/0263276409104965

[15] Ayoub, M. (2013) Islam: Faith and History. Oneworld Publications, London.

[16] Al-Raysuni, A. (2011) Imam al-Shatibi's Theory of the Higher Objectives and Intents of Islamic Law. The International Institute of Islamic Thought, London.

[17] Attia, G.E. (2010) Towards Realization of the Higher Intents of the Islamic Law: Maqasid al-Shari'ah, a Functional Approach. International Institute of Islamic Thought, Herndon.

[18] Auda, J. (2008) Maqasid al-Shari'ah: A Beginner's Guide. International Institute of Islamic Thought, London. https://doi.org/10.2307/j.ctvkc67c6

[19] Auda, J. (2010) Maqasid al-Shari'ah as Philosophy of Islamic Law. International Institute of Islamic Thought, Herndon.

[20] Naqvi, S.N.H. (2013) Islam, Economics, and Society (RLE Politics of Islam). Routledge, New York. https://doi.org/10.4324/9780203381373

[21] Sidahmed, A.S. (2018) Islamic Fundamentalism. Routledge, New York. https://doi.org/10.4324/9780429499593

[22] Asutay, M. (2007) A Political Economy Approach to Islamic Economics: Systemic Understanding for an Alternative Economic System.

[23] Nasr, S.H. and Religionsphilosoph, I. (2010) Islam in the Modern World: Challenged by the West, Threatened by Fundamentalism, Keeping Faith with Tradition. HarperOne, New York.

[24] Hillenbrand, C. (2018) The Crusades: Islamic Perspectives. Routledge, New York. https://doi.org/10.4324/9781315063003 